\title{
The Lesson Learned from Use of Toll-Free Telephone Line for Case Notification of Ebola Outbreak in Western Area, Sierra Leone
}

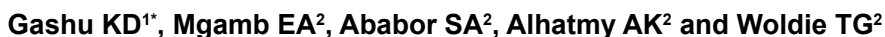

${ }^{1}$ Department of Health Informatics, College of Medicine and Health Sciences, University of Gondar, IPH, Ethiopia ${ }^{2}$ African Union Support to Ebola Outbreak in West Africa (ASEOWA), EVD Surveillance Team, Sierra Leone, West Africa

\begin{abstract}
Background: The prompt spread and advancements of mobile technologies has come to address health priorities in generating real time information for evidence based decisions and to improve timely response to emergencies. According to WHO's Global Observatory for electronic Health survey; most frequently reported Mobile Health initiatives were: health call centres, emergency toll-free telephone services and mobile telemedicine. Sierra Leone was one of severely affected countries in Ebola Virus Disease outbreak 2014/15. Toll-free line, Walk-Ins and Community suspects were main case notification strategies nationally affected for identifying Ebola Virus Disease (EVD) suspected cases and deaths in the community. The main objective of this study was to assess the role of Toll-free line played in the response against Ebola Virus Disease outbreak.
\end{abstract}

Method: The study was based on review of records in Ebola Virus Disease alert reports of Western Area Urban and Rural from $26^{\text {th }}$ January to $28^{\text {th }}$ June 2015. All Ebola Virus disease suspected case and death alert records were classified based on surveillance strategies; Toll-free telephone call, Walk-Ins and Community suspects. SPSS Version 20 was used for data analysis. One-way Analysis of Variance (ANOVA) test was applied to evaluate the difference in number of cases and deaths notified via these surveillance strategies. $P$-Value was calculated and $P \leq 0.05$ was reported as having significant difference in generating more suspected cases and deaths by each EVD surveillance strategies.

Result: The result showed that 11,303 alerts were registered in western area within 22 weeks. Out of which 7,059 $(62 \%)$ of alerts were notified by Toll-free alert. One-way Analysis of Variance (ANOVA) revealed that Toll-free telephone call based surveillance was playing significantly higher; $[F(2,63)=184.76, p<0.0001]$ role in generating EVD suspected cases and deaths than Walk-Ins and Community suspect strategies.

Conclusion: In conclusion, Toll-free telephone line has played significantly higher role in generating EVD suspected cases and deaths in the community. Lessons shall be adopted and scaled-up by all African nations and the world at large for rapid emergency responses; however, related challenges needs to be more investigated.

Keywords: Ebola virus disease; Toll-free line; Sierra Leone; Mobile health

\section{Background}

The unprecedented spread of mobile technologies as well as advancements in innovative application has come to address health priorities as new field of electronic health, known as Mobile Health (m-Health). Function of $\mathrm{m}$-Health includes: Emergency toll-free telephone services for managing emergencies and disasters, mobile telemedicine, appointment reminders, community mobilization and health promotion, treatment compliance, mobile patient records, information access, patient monitoring, health surveys and data collection, surveillance, and decision support systems. The initiative of $\mathrm{m}$-Health is being applied in maternal and child health, and programmes reducing the burden of the diseases linked with poverty, including HIV/ AIDS, malaria, and tuberculosis. M-Health applications are being tested in such diverse scenarios as improving timely access to emergency and general health services and information, managing patient care, reducing drug shortages at health clinics, enhancing clinical diagnosis and treatment adherence, among others. According to the International Telecommunication Union there are now close to 5 billion mobile phone subscriptions in the world, with over $85 \%$ of the world's population now covered by a commercial wireless signal [1]. Based on the survey done by international Telecommunications Union Mobile-cellular penetration had reached 66 per cent in Africa and growth continues even stronger than other regions of the world by the end of 2013. In the survey Mobile phone subscriptions in Sierra Leone was reported to be $20.36 \%$ [2]. There are an estimated 2.2 million mobile users in the country [3].

Sierra Leone consists 14 districts; Western Area Urban was the most Ebola Virus Disease (EVD) affected area. Nationally, about 8,664 cases and 3,566 deaths were confirmed EVD during the study period [4]. The incidence had been dramatically decreased in the country; however, new cases have been investigated from Kambia, Port Loko and Western Area Urban (Magazine Wharf) districts as of July $5^{\text {th }} 2015$ [5]. Nationally, three main case notification strategies were affected in identifying EVD suspected cases and deaths in the community. The first was Walk-Ins: Where suspected cases were identified by care providers in health institutions while a patient seeking healthcare services. The second strategy was community suspect: In which the task force in every ward will conduct house to house active case search and will directly link to

*Corresponding author: Gashu KD, Department of Health Informatics, College of Medicine and Health Sciences, University of Gondar, IPH, Ethiopia, Tel: 251 581110243; E-mail: kassahundessie@gmail.com

Received June 15, 2016; Accepted August 03, 2016; Published August 10, 2016

Citation: Gashu KD, Mgamb EA, Ababor SA, Alhatmy AK, Woldie TG (2016) The Lesson Learned from Use of Toll-Free Telephone Line for Case Notification of Ebola Outbreak in Western Area, Sierra Leone. J Health Med Informat 7: 242. doi: 10.4172/2157-7420.1000242

Copyright: @ 2016 Gashu KD, et al. This is an open-access article distributed under the terms of the Creative Commons Attribution License, which permits unrestricted use, distribution, and reproduction in any medium, provided the original author and source are credited. 
Citation: Gashu KD, Mgamb EA, Ababor SA, Alhatmy AK, Woldie TG (2016) The Lesson Learned from Use of Toll-Free Telephone Line for Case Notification of Ebola Outbreak in Western Area, Sierra Leone. J Health Med Informat 7: 242. doi: 10.4172/2157-7420.1000242

the assigned Disease Surveillance Officer (DSO). And the third one was Toll-Free telephone Line: In which any person encountered suspected case and death will forwards a toll-free call to national command centre so that EVD task forces will be alerted.

In Sierra Leone, a Toll-free line was established in 2012 and 24 $\mathrm{h}$, seven days open for the public to call and register their concerns, enquiries and observations with regards on the operations of the free health care service for pregnant women, lactating mothers and children under age of five.

Due to EVD outbreak it had been shifted and fully engaged as Ebola hot-line since August 2014 across Sierra Leone [6]. The operation is based on a charge free call initiated by a community member when they see anybody manifesting sign and symptoms EVD and deaths of any causes. The National command centre will receive the preliminary information from caller, and then the District Ebola Response Centre (DERC) Alert Team will directly access that preliminary information online and will immediately alert the assigned task force in the area. The informed DSO has to investigate the case within $24 \mathrm{~h}$ of the initial call. So that the case will be isolated and transported to Holding Centre for laboratory examination and if it was death will be swabbed, decontaminated and taken to safe and dignified burial. The DSO will finally probe family to line-list individuals with history of possible and known contact with the patient. This line-list will be used for quarantining those contacts to be followed for 21 days of incubation period if the case is eventually confirmed positive. As indicated in Figure 1.

\section{Rationale of the study}

Uncertain Public health emergencies are globally coming devastating in human welfare. Ebola was one of a global-concern emergency in which 27,609 cases and 11,261 deaths had been reported worldwide as of July $5^{\text {th }} 2015$ [5].

Ebola viruses, is classified as a 'biosafety level four (BSL4) pathogen. The most dangerous of all viruses, without a known cure or vaccine yet. The need of Rapid emergency response was vital in saving lives. Electronic devices like Mobile phones play great role to enhance real time information and evidence based decisions in rapid response [7].

Investigators perceived that very little is known about the role of tollfree telephone line in Ebola virus disease surveillance. The ultimate aim of this survey was to scientifically document best practices on role of toll-free lines in Ebola emergency control. These will enable lessons to be adopted and scaled-up by other countries in African and the world.

\section{Methods}

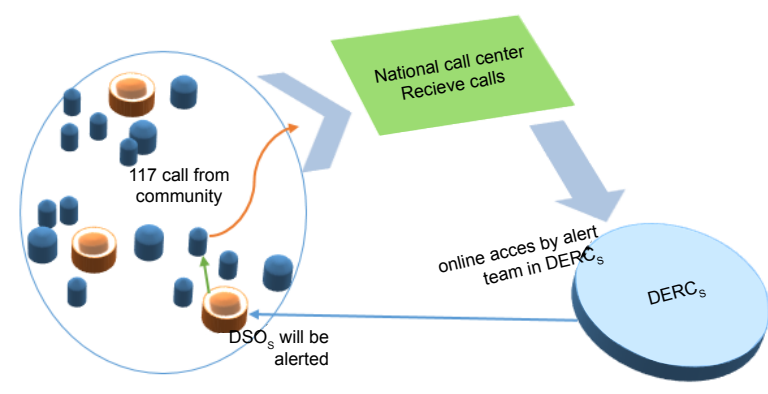

Figure 1: Schematic view of toll-free telephone line operation from $26^{\text {th }}$ January to $28^{\text {th }}$ June 2015 in Western Area, Sierra Leone.

\section{Study area}

Western Area Urban and Rural are among 14 districts in Sierra Leone. Western Area Urban was the highest populated $(1,473,873)$ out of all districts. Out of the national Ebola Virus Disease burden, 26\% $(2,265)$ of EVD cases and 23\% (805) of EVD related deaths were from Western Area Urban. Similarly western Area Rural was among districts worse hit by the outbreak during the study period [8]. Both urban and rural districts were commanded by one centre called Western Area DERC.

\section{Data source}

The data was taken from open daily and weekly reports of alert records from EVD surveillance from Western Area urban and rural in Sierra Leone. The study area was selected based on the high burden of the outbreak. Data was taken from the National Ebola Response Centre (NERC) and Western Area District Ebola Response Centre (DERC). The study period was from $26^{\text {th }}$ January to $28^{\text {th }}$ June 2015 . The study period was selected based on convenience of availability of records.

\section{Statistical analysis}

The study was based on review of records in Ebola Virus Disease alert reports of Western urban and rural area, Sierra Leone. SPSS Version 20 was used for data analysis. All alert records of suspected cases and deaths of Ebola Virus disease were classified based on surveillance strategies; namely: Toll-free telephone call, Walk-Ins and Community suspects. One-way ANOVA test was applied to evaluate the difference in number of cases notified via these surveillance strategies. P-Value was calculated, $\mathrm{P} \leq 0.05$ shows evidence for significant difference of the surveillance strategies in generating cases.

\section{Result}

\section{Role of toll-free line played in the response}

In Western Area, a total of 11,303 alerts were notified from $26^{\text {th }}$ January to $28^{\text {th }}$ June 2015 . Out of a total number of alerts 7,059 (62\%) were notified by Toll-free line followed by Walk-Ins and community suspects (Table 1).

The time trend shows that toll-free line notification was consistently high among all notification strategies throughout the study period. The highest alert record was in week-13 which accounts 525 alert notifications a week. Walk-In notifications were also consistently higher than that of community suspects (Figure 2).

The cumulative number of alert notifications has been displayed in the figure below based on 22 weeks of outbreak response and three strategies of notifications. On $7^{\text {th }}$ week of the study period, Incidence of EVD was picked ( 88 confirmed cases) from a total of 675 alert notifications by toll-free alert, Walk-ins and community suspects in the week (Figure 3).

In Western Area Urban and of Rural; a total of 6,969 deaths of any cause were notified by toll-free line in the last 22 weeks, which means

\begin{tabular}{|c|c|c|}
\hline Strategies used & No. of cases alerted & Percentage \\
\hline Toll-free Alert & 7059 & $62 \%$ \\
\hline Walk-Ins & 3049 & $27 \%$ \\
\hline Community suspects & 1195 & $11 \%$ \\
\hline Total & 11303 & $100 \%$ \\
\hline
\end{tabular}

Table 1: Number of cases alerted through toll-free Call, walk-ins and community suspects from $26^{\text {th }}$ January to $28^{\text {th }}$ June 2015 in Western Area, Sierra Leone. 
Citation: Gashu KD, Mgamb EA, Ababor SA, Alhatmy AK, Woldie TG (2016) The Lesson Learned from Use of Toll-Free Telephone Line for Case Notification of Ebola Outbreak in Western Area, Sierra Leone. J Health Med Informat 7: 242. doi: 10.4172/2157-7420.1000242

Page 3 of 4

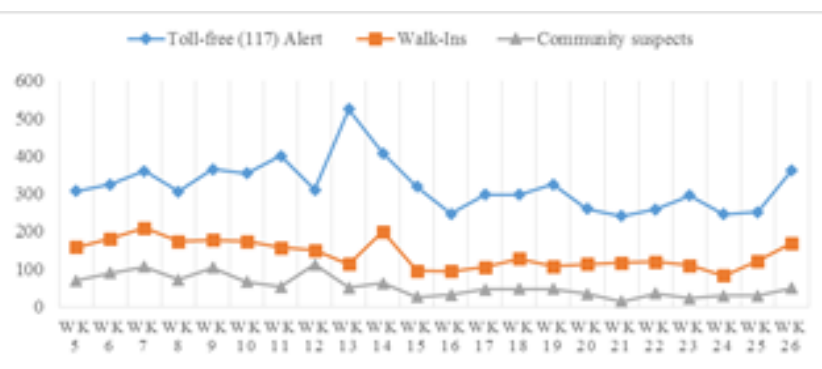

Figure 2: Time trend of weekly EVD notifications through toll-free call, walk-ins and community suspects from $26^{\text {th }}$ January to $28^{\text {th }}$ June 2015 in Western Area Sierra Leone.

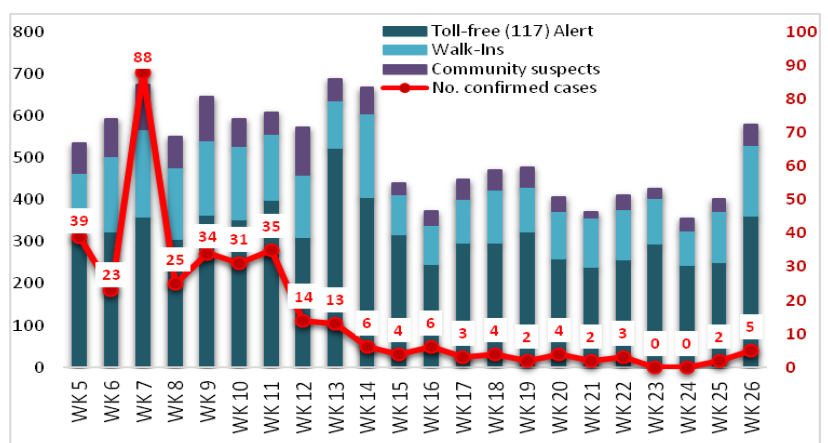

Figure 3: Number of confirmed versus notifications of suspects cases from $26^{\text {th }}$ January to $28^{\text {th }}$ June 2015 in Western Area, Sierra Leone.

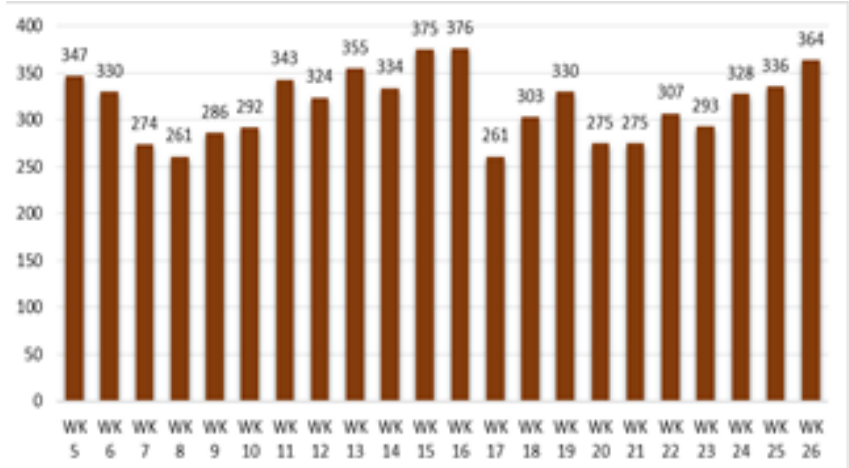

Figure 4: Trends of weekly death notification by toll-free call from $26^{\text {th }}$ January to $28^{\text {th }}$ June 2015 in Western Area, Sierra Leone.

an average of 317 death alerts notified every week in the area. Detail has been displayed in the figure below. The total weekly EVD alert notifications were consistent throughout the study period (Figure 4).

In Western Area Urban and of Rural, an average of 321 by toll-free line; 139 by Walk-Ins and 54 by community-suspect alert notifications were observed in the period (Table 2).

One way ANOVA test shown that The three strategies used in Western Area Urban and of Rural were found to have significantly different mean of EVD related alert notification; $F(2,63)=184.76$, $\mathrm{p}<0.0001$ (Table 3 )

\section{Discussion}

The swift control of EVD outbreak was likely facilitated by the early

\begin{tabular}{|c|c|c|c|c|}
\hline Groups & Week Count & $\begin{array}{c}\text { Sum of Alerts } \\
\text { notified }\end{array}$ & Average & Variance \\
\hline Toll-free Call & 22 & 7059 & 321 & 4472 \\
\hline Walk-Ins & 22 & 3049 & 139 & 1363 \\
\hline $\begin{array}{c}\text { Community } \\
\text { Suspects }\end{array}$ & 22 & 1195 & 54 & 794 \\
\hline
\end{tabular}

Table 2: Weekly average notifications through toll-free call, walk-ins and community suspects from $26^{\text {th }}$ January to $28^{\text {th }}$ June 2015 in Western Area, Sierra Leone.

\begin{tabular}{|c|c|c|c|c|c|c|}
\hline Source of Variation & SS & df & MS & F & P-value & F crit \\
\hline Between Groups & 816725.9 & 2 & 408363 & 184.8 & $4.41 E-27$ & 3.149 \\
\hline Within Groups & 139242.7 & 63 & 2210.2 & - & - & - \\
\hline Total & 955968.6 & 65 & - & - & - & - \\
\hline
\end{tabular}

Table 3: One way ANOVA test of mean notification difference among toll-free alert, walk-ins and community suspects from $26^{\text {th }}$ January to $28^{\text {th }}$ June 2015 in Western Area, Sierra Leone.

detection of the index case followed by intensive contact tracing efforts and the subsequent isolation of infected secondary cases [9]. On the other hand, delay in detection of cases will speed up the spread of the virus. According to WHO second global survey on e-Health, an eventbased telephone hotlines like, Cam e-WARN in Cambodia, Senegal and similar system, in countries like Indonesia, Papua New Guinea, and Viet Nam used by the population to report specific cases of disease to promptly respond to major outbreaks. This Cellular technology provides a fast, simple, and affordable platform implemented for the rapid detection of early stage disease outbreaks [10].

In Sierra Leone, toll-free line, Walk-Ins and communitysuspects were the three main case notification strategies used in EVD surveillance. In this study, a total of 11,303 alerts were notified in Western Area Urban and Rural of Sierra Leone within the study period. Toll-free line accounts $62 \%(7,059)$ of all the alert notifications followed by Walk-Ins (27\%) and community-suspects (11\%). An average of 321 (by toll-free line); 139 (by Walk-Ins) and 54 (by community-suspect) alert notifications were observed per week which shows that vast majority of alerts were notified by toll-free call.

Similarly analysis of One way ANOVA test also shown that the three strategies used in Western Area Urban and of Rural were found to have significantly different mean of EVD related alert notification; $\mathrm{F}(2,63)=184.76, \mathrm{p}<0.0001$. This indicates that the role of toll-free line played in notification of cases was much higher followed by walk-ins and community-suspect notifications. This could be due to intensive sensitization works done on toll-free, may be charge free service sicking attitude. The total weekly EVD alert notifications were fairly consistent throughout the study period; however, the incidence declines ahead of time. The time trend of toll-free line notification was able to produce the largest alert notifications than other strategies. The trends of WalkIn notifications were also consistently higher than that of communitysuspects.

Based on the second global e-Health survey, toll-free telephone services reported $88 \%$ for emergency alerts in South-East Asia Region; $63 \%$ on lower-middle income Countries and $58 \%$ on high-income countries. The African Region reported the least (31\%) activity in this category, however few African countries had disease-specific emergency toll-free telephone services; like: Zimbabwe reported launching a telephone line for citizens to report cholera cases; Madagascar had a service to support victims of domestic violence; and Togo gave an account of an emergency toll-free telephone service set up for citizens 
Citation: Gashu KD, Mgamb EA, Ababor SA, Alhatmy AK, Woldie TG (2016) The Lesson Learned from Use of Toll-Free Telephone Line for Case Notification of Ebola Outbreak in Western Area, Sierra Leone. J Health Med Informat 7: 242. doi: 10.4172/2157-7420.1000242

to obtain information on H1N1 and TB [10].

In 2012 Uganda operationalized m-health platform known as mTrac; in Ebola outbreak response. It enabled engaging the community via a free SMS hotline to report suspected Ebola cases. The messages had been reached 2,000 in the districts every two days [11]. Similarly, Senegal's Ministry of Health were encouraging individuals to alert health authorities of anyone showing signs of a fever and bleeding by calling a toll-free number. Sent in response to Senegal's first EVD case, the SMSs were delivered using the mobile Diabetes platform [12]. Mobile phone communications from village to district and to the centre was one of the mechanisms instituted and more effected in Ebola epidemic containment in Gulu district Uganda; ultimately, motorized and foot patrols at the community level urgently alerted.

In the first ten weeks of this study period, intensive notifications of cases were reported. Eventually, EVD incidence was at pick stipulation. This could be due to; the higher the incidence, more efforts would be exerted on case surveillance and more EVD cases will be investigated. In Western Area Urban and of Rural; a total of 6,969 deaths of any cause were notified by toll-free line in the last 22 weeks. Which means an average of 317 death alerts were notified every weeks in the area?

\section{Limitations of the study}

The study was ultimately focussing on alert records of suspected cases not exactly on confirmed cases that lead to over reporting of use of toll-free line. It was not able to assess challenges related to operation of toll-free telephone line.

\section{Conclusion}

In general, the findings of this study showed that toll-free line played major role in Ebola Virus disease surveillance. So that it was immense lesson to be scaled-up by all Africans and the world as well. Researchers shall conduct community based survey on user satisfaction and major challenges of toll-free line on emergency response.

\section{Authors' Contributions}

KDG contributed on the initiation of the topic and design of the study. EAM, SAA, AKA contributed on data analysis and TGW on report writing finally all authors have approved the manuscript.

\section{Ethical Issues}

Data was open source in daily and weekly EVD reports from NERC.

\section{Acknowledgement}

We would like to acknowledge National Ebola Response Centre and Western Area District Ebola Response Centre, Sierra Leone for their open source of data We also would like to appreciate African Union African Union Support for Ebola Outbreak in West Africa (ASEOWA), Sierra Leone for the chance given to support Africans by Africans that enable this research team to be acted accordingly.

\section{References}

1. International Telecommunications Union (ITU) (2010) The world ICT facts and figures. Geneva.

2. International Telecommunication Union (ITU) (2012) Measuring the Information Society 2012, ITU, Geneva.

3. Republic of Sierra Leone (2014) National communication strategy for Ebola response in Sierra Leone. MOHS. EVD situational report, (sit-rep) Sierra Leone.

4. World Health Organization (2015) Ebola Situation Report.

5. Augustine Samba (2012) In Sierra Leone, 117 Launched as Toll Call Line for Free Health Care. Awareness Times Newspaper in Freetown 17: 16.

6. CDC (2015) Viral Special Pathogens Branch (VSPB) Viral Haemorrhagic Fevers Fact Sheet.

7. MOHS (2015) EVD situational report, (sit-rep) Sierra Leone.

8. Shuaib F, Gunnala R, Musa EO, Mahoney FJ, Oguntimehin O, et al. (2014) Ebola virus disease outbreak - Nigeria, July-September 2014. MMWR Morb Mortal Wkly Rep 63: 867-872

9. World Health Organization (2011) mHealth: New Horizons for Health through Mobile Technologies: Based on the Findings of the Second Global Survey on eHealth. Global Observatory for eHealth Series.

10. Davis Musinguzi, mHealth Working group email excerpt from UNICEF/Uganda, Health Systems Strengthening.

11. USAID (2014) Use of technology in the Ebola response in West Africa.

12. Okware SI, Omaswa FG, Zaramba S, Opio A, Lutwama JJ, et al. (2002) An outbreak of Ebola in Uganda. Trop Med Int Health 7: 1068-1075. 